Association for Information Systems

AIS Electronic Library (AISeL)

\title{
Enter the Shark Tank: The Impact of Business Models on Early Stage Financing
}

Timo Phillip Böttcher

Technical University of Munich, Chair for Information Systems and Business Process Management, Garching, Germany

Valentin Bootz

Technical University of Munich, Chair for Information Systems and Business Process Management, Garching, Germany

Tetiana Zubko

Technical University of Munich, Chair for Information Systems and Business Process Management, Garching, Germany

Jörg Weking

Technical University of Munich, Chair for Information Systems and Business Process Management, Garching, Germany

Markus Böhm

Technical University of Munich, Chair for Information Systems and Business Process Management, Garching, Germany

See next page for additional authors

Follow this and additional works at: https://aisel.aisnet.org/wi2021

Phillip Böttcher, Timo; Bootz, Valentin; Zubko, Tetiana; Weking, Jörg; Böhm, Markus; and Krcmar, Helmut, "Enter the Shark Tank: The Impact of Business Models on Early Stage Financing" (2021).

Wirtschaftsinformatik 2021 Proceedings. 6.

https://aisel.aisnet.org/wi2021/JDigitalInnovation16/Track16/6

This material is brought to you by the Wirtschaftsinformatik at AIS Electronic Library (AISeL). It has been accepted for inclusion in Wirtschaftsinformatik 2021 Proceedings by an authorized administrator of AIS Electronic Library (AISeL). For more information, please contact elibrary@aisnet.org. 


\section{Presenter Information}

Timo Phillip Böttcher, Valentin Bootz, Tetiana Zubko, Jörg Weking, Markus Böhm, and Helmut Krcmar 


\title{
Enter the Shark Tank: The Impact of Business Models on Early Stage Financing
}

\author{
Timo Phillip Böttcher ${ }^{1}$, Valentin Bootz ${ }^{1}$, Tetiana Zubko ${ }^{1}$, Jörg Weking ${ }^{1}$, Markus \\ Böhm ${ }^{1}$ and Helmut Krcmar ${ }^{1}$ \\ ${ }^{1}$ Technical University of Munich, Chair for Information Systems and Business Process \\ Management, Garching, Germany \\ \{timo.boettcher, v.bootz, tetiana.zubko, joerg.weking, markus.boehm, \\ helmut.krcmar\} @tum. de
}

\begin{abstract}
Investments are the necessary fuel for startup development. However, new ventures face difficulties in obtaining financial investments. The investors aim to invest in startups with high success chances and quick return on investment. The business model (BM) of a startup was proven to be a determinant of its success. However, there is a lack of research on the influence of the BM on the amount of received seed funding. This study analyzes the BMs of 72 startups and the amount of received seed investment. We applied Pearson's productmoment correlation tests to calculate the correlation between these variables. Our research shows a correlation between the BM and the amount of received seed investment. We identify the patterns Two-Sided Market, Layer Player, and Freemium to have a significant positive effect on the investment sum. This research guides entrepreneurs in BM design and contributes to the discussion of success factors for startup success.
\end{abstract}

Keywords: business model, startup, financing.

\section{Introduction}

"It's a unique idea there's no question, the question is it a good idea, and if the Sharks hear a good idea, they'll fight each other for a piece of it." - Phil Crowley on Shark Tank [1]

Entrepreneurs face a chicken-egg-problem in the early stages of founding a new startup: They need money to finance their early-stage tasks of market evaluation, product development, and market entry. The chances of success depend heavily on this initial funding [2], since they do not qualify for bank loans. However, as they do not have much to present to potential investors but their value proposition and the plan on how to create and capture this value, which is articulated in the business model [3], getting this early-stage financing is a tough task $[4,5]$. On the other side, investors take significant risks when investing in early-stage startups. They cannot rely on early market success, sales figures, or other prominent investors' involvement. They need to evaluate the potential success based on the entrepreneurs' business model $[6,7]$. Consequentially the available capital for such investments is also scarce [6]. Thus, identifying a good, success-promising business model is crucial for either side. 
Considering that $90 \%$ of the new startup ventures fail, investing in startups comes with very high risk [8]. Thus, investors seek ways to evaluate the quality of startups to reduce these risks and increase their chances of receiving a return on investment [8]. However, screening early-stage ventures is a highly noisy process, and evidence on the plausibility of their methods from empirical studies is inconclusive [9]. Due to a variety of challenges, such as limited data at the time of founding and a comparatively small number of successful ventures, the question about the prediction of a startup success remains an open topic of the research [10].

Both sides, entrepreneurs and investors, spend much effort in finding each other and maximize their profit. To evaluate this fit, the business model has emerged recently [11]. It represents a formal, conceptual model of the firm's strategy in terms of its value proposition, value creation, and value capture [12]. For startups, it captures the business idea and the set of activities to create value [13], that can be presented to potential investors [14].

A growing body of scholars has studied the correlation between startup performance and its selected business model [15-18]. The startup performance was measured by outcomes such as startup survival [17] or growth against revenue [15]. Both qualitative and quantitative research show that there is a correlation between a startup's business model and its performance. While research on established firms shows, that unique business models are a source of competitive advantage and even disruption [12, 19, 20], and research on startups in later stages shows that it is a critical factor for survival and success [21-23], research lacks acks investigations in startups' early stages. Even though the early stages of a startup are characterized by ideation and business planning, the influence of the business model on seed investment in startups' early stages is unknown [4]. Therefore, we analyze the relationship between applied business model patterns and the amount of seed investment received by startups. We address the following research question:

\section{RQ: How important is the business model for startups to receive seed investment?}

This paper performs statistical analysis about how the amount of startup seed investments correlates with the applied business model pattern. Our research provides an analysis of specific business model patterns and targets whether some business model patterns receive higher or lower levels of seed investment. For this purpose, we use an industry-independent dataset of 72 startups from the USA. The startups are categorized according to the 55 business model patterns developed by Gassmann, Frankenberger and Csik [24]. We performed a point-biserial correlation to test whether the applied business model pattern influences the seed funding amount.

We contribute to the business model and entrepreneurship research by showing that the applied business model patterns influence the seed investment received by startups. For entrepreneurs, this provides guidance for business model design. For investors, the results help guide their investment decisions.

The remainder of this paper is structured as follows. The second chapter describes related work, including relevant BM literature. The third chapter details the methodology to create and analyze the dataset. In the fourth chapter, we present the 
results of the statistical analysis, followed by the discussion and implications of these results in chapter five. The final chapter concludes with the contributions of the paper and avenues for future research.

\section{Related Work and Hypothesis Development}

In recent years, both academics and practitioners paid much attention to the concept of the business model. Originating in the emergence of e-commerce, digitalization, and digital transformation are key drivers of the concept's popularity. As a formal, conceptual representation of strategy it presents the firm's proposition on how to achieve its goals [14]. It describes how the firm interacts with its environment to create, capture, and deliver value to the customer [12]. Therefore, the business model can be used as a unit of analysis for explaining how firms plan and execute their strategy [25].

Based on the firm's resource-based view, strategy aligns resources and capabilities to achieve a competitive advantage and superior firm performance [26]. Business model scholars build upon this theory to argue the business model, as an articulation of strategy, influences firm performance [27]. A unique business model imposes a superior value creation and capture strategy. It may even be more influential on the created value than the offered product itself, and the business model's innovations provide greater opportunities than innovations of the product [12, 28]. For example, as we can observe in the platform economy, firms can create a differentiating value proposition and competitive advantage by creating a unique and innovative business model. Still, scholars point out that the business model is no holy grail, and no guarantees of success can be given only based on the business model [29]. However, it provides a mean for strategic planning in complex and digital ecosystems as it illustrates the strategy and forces management to question their options [25].

As these findings mainly rely on qualitative research approaches, recent reviews of the field call for more quantitative research to strengthen and validate the existing findings. Most influential are two studies by Zott and Amit [22, 23] analyzing the effect of efficient and novel business model designs on firm performance. These independent constructs were applied in subsequent studies, e. g. Brettel, Strese and Flatten [30] and Kulins, Leonardy and Weber [31]. In the context of entrepreneurship, the business model was shown to influence startup survival [17, 32]. [33] showed that the novelty of business model designs influences startup investors' decisions. Kulins, Leonardy and Weber [31] revealed how business model design influences entrepreneurial firms' market value after they went public.

Based on the qualitative and quantitative researches on the business models, there is a connection between the selected business model and the probability of a startup's success. We argue that the business model of a startup is already influential in its initial phases. Considering that investors need to rely partly on the presented business model and aim to invest in companies with higher success chances and survival rates, to earn a high rate of return from their investments [34], we put forward the hypothesis that the applied business model pattern influences the amount of seed investment a startup receives, visualized in Figure 1. 
Hypothesis: The applied business model pattern influences the amount of seed investment received by a startup.

Figure 1. Theoretical Model

\begin{tabular}{|l|l|l|}
\hline Applied Business Model Pattern & influences & Amount of Seed Funding \\
\cline { 3 - 3 } & &
\end{tabular}

\section{Dataset and Research Method}

Our dataset is based on data from Crunchbase (www.crunchbase.com). This platform provides company insights, including early-stage funding data of startups and their value proposition [35]. To ensure recency, yet avoid any effects linked to the expected decline in venture capital due to the COVID-19 pandemic [36], we looked at seed funding rounds in the fourth quarter of 2019. To obviate inconsistency with investment levels among different countries, we only selected startups founded in the US. A total of 593 startups matched our selection criteria.

Out of these, we randomly selected a sample of 100 startups. Following Böhm, Weking, Fortunat, Mueller, Welpe and Krcmar [15], we coded 55 binary values representing the 55 business model patterns developed by Gassmann, Frankenberger and Csik [24]. The binary values indicate whether a pattern was applied (1) or not (0). This coding resulted in a vector, as illustrated in Table 1, for each startup.

Table 1. Example of encoding table of business model pattern applied by startup

\begin{tabular}{|l|l|l|l|l|l|l|l|l|l|}
\hline BMP & 1 & 2 & 3 & 4 & $\ldots$ & 52 & 53 & 54 & 55 \\
\hline Appl. & 0 & 0 & 0 & 1 & $\ldots$ & 0 & 1 & 1 & 0 \\
\hline
\end{tabular}

The business model patterns are labeled 1 to 55 in alphabetical order. To gather the required information for coding, we analyzed the startups based on their Crunchbase profile, their website, and other publicly available information such as news, press reports, and founders' interviews. To ensure reliability, the encoding was performed by 2 of the authors in regular meetings. The coding was done between May and June 2020. During the coding process, 28 of the 100 sampled startups had to be removed from the sample, since the applied business model patterns could not be confidently identified based on the available data.

Figure 1 visualizes the coverage of business model patterns in our dataset of the remaining 72 startups. Out of 55 patterns, 48 were applied by at least one of the startups in the dataset. The five most frequently applied patterns were \#11 Digitalization (73,6\%), \#48 Subscription (47,2\%), \#15 Flat Rate (43,1\%), \#32 Open Business Models $(40,3 \%)$ and \#18 Freemium $(38,9 \%)$. Overall, the dataset shows a bias towards patterns linked to digital products and services despite being unbiased with regards to the industry. 
Figure 2. Coverage of Business Model Patterns

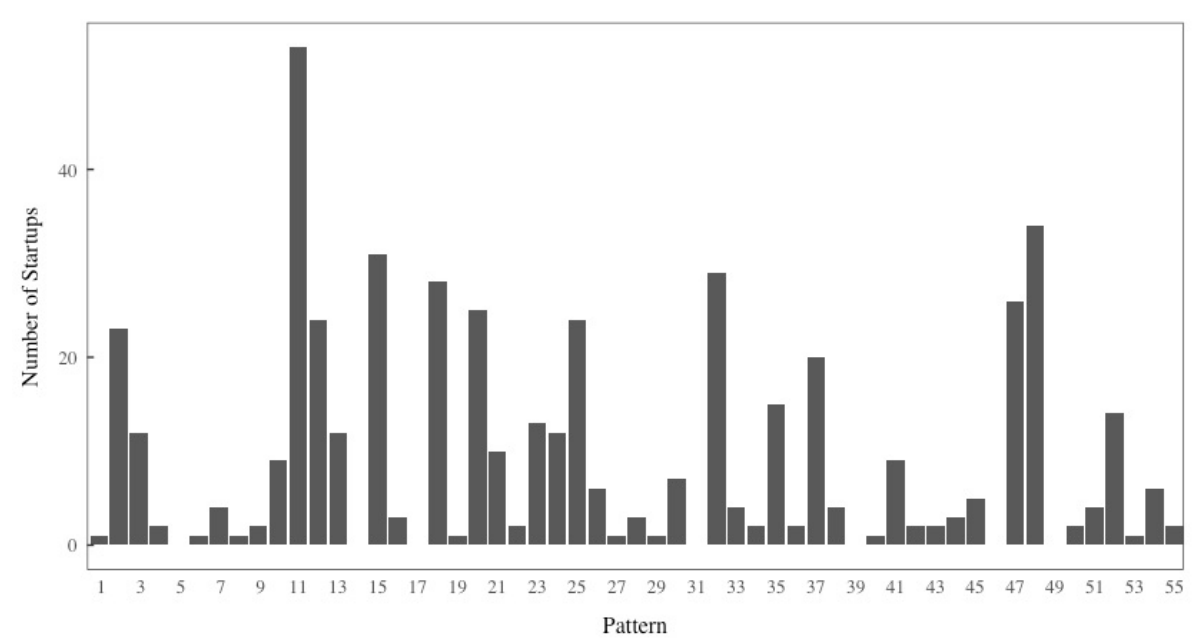

To test our hypothesis that the applied business model patterns influence seed funding, we performed point-biserial correlation tests. This equals Pearson's product-moment correlation with one variable represented as interval/ratio data and one dichotomous variable on a nominal/categorical scale [37]. The point-biserial correlation tests provide a coefficient as a measure of strength and direction of the correlation. In our case, the received seed funding (in US dollar) provides our ratio data, while the dichotomous variable indicates the use of the analyzed business model pattern. This allows us to analyze the seed funding received by startups that applied the business model pattern under investigation and compare it with those startups that did not apply it. We have minimized outlier effects caused by small sample sizes by limiting our analysis to these business model patterns where both comparison groups (pattern applied / not applied) contained at least 10 startups. This reduced the number of analyzed patterns from 55 to 17.

After analyzing the impact of all 55 patterns, we used the hierarchical taxonomy by [38] that identifies the following high-level business model patterns: merchant odel groups wholesalers and retailers of goods and services [39]. Multi-Sided Platforms serve two or more interdependent customer segments, where both segments are required to make the business model work [38]. Besides, we generalize focus on a particular Customer Group or market segment and use of a specific Pricing Model or Revenue Stream and group pattern that change the Value Network or the way it is interacted with and ones that offer certain products or services (Value Proposition) or develop an offering in a certain way (Value Proposition Development) [17].

Table 2 shows the mapping of the original pattern to the high-level generalization. Whenever the original patterns were not as frequent, we grouped startups that applied at least one of them to analyze the high-level pattern's impact. For example, the patterns Orchestrator (2,8\% of the total sample) and Self Service (6,9\% of the total sample) were rather infrequent individually. However, we used them when analyzing startups 
that applied at least one Value Network pattern (45,8\% of the total sample). Besides, the high-level patterns enabled in-group comparisons (e.g., Subscription and Pay-perUse).

Table 2. High-Level Pattern Mapping

\begin{tabular}{ll}
\hline High-Level Pattern & Business Model Pattern \\
\hline Merchant Model & Direct Selling, E-Commerce, Shop-in-Shop, Supermarket \\
\hline Multi-Sided Platform & Affiliation, Peer-to-Peer, Two-Sided Market \\
\hline Customer Group & Aikido, Long Tail, Target the Poor, Ultimate Luxury \\
\hline Pricing Model & Add-on, Auction, Barter, Fractional Ownership, Freemium, \\
& No Frills, Pay What You Want, Robin Hood \\
\hline Revenue Stream & Cash Machine, Crowd Funding, Flat Rate, Franchising, \\
& Hidden Revenue, License, Pay-per-Use, Performance- \\
& based Contracting, Rent Instead of Buy, Subscription \\
\hline Value Network & Integrator, Layer Player, Orchestrator, Revenue Sharing, \\
& Self Service \\
\hline Value Proposition & Cross Selling, Customer Loyalty, Experience Selling, \\
& Guaranteed Availability, Ingredient Branding, Leverage \\
& Customer Data, Lock-In, Make More Of It, Mass \\
& Customization, Razor and Blade, Reverse Innovation, \\
& Solution Provider, Whitelabel \\
\hline Value Proposition & $\begin{array}{l}\text { Crowdsourcing, Digitalization, From Push to Pull, Open } \\
\text { Business Models, Open Source, Reverse Engineering, } \\
\text { Development } \\
\text { Trash to Cash, User Designed }\end{array}$ \\
\hline
\end{tabular}

\section{$4 \quad$ Results}

The results from Pearson's product-moment correlation tests on our original patterns, where our analysis indicates the effects of applying individual patterns on seed funding, are shown in Table 3. Positive and negative correlation coefficients $\left(r_{p b}\right)$ respectively indicate an increase or decrease in received funding when the specific pattern is applied, while a coefficient of zero indicates no correlation. The $p$-values serve as indicators for statistical significance, representing the probability of observing the data seen in our analysis if applying a particular pattern does not affect seed funding [40].

Out of the 17 patterns that were applied by at least $n=10$ startups in our dataset, nine revealed a correlation coefficient with a magnitude larger than 0.1 . For Two-Sided Market, Layer Player, and Freemium, our data indicated the strongest correlations with larger than 0.2 correlation coefficients. Direct Selling and Aikido were the only patterns that showed negative correlations. However, only the patterns Two-Sided Market and Layer Player resulted in a $p$-value $<0.05$ indicating significance. Since the $p$-value for the Freemium pattern is only slightly above this 0.05 threshold with a $p=0.0592$, but below the $p=0.1$ threshold, we consider this correlation significant. 
Table 3. Pearson's Product-Moment Correlations

\begin{tabular}{llll}
\hline Business Model Pattern & $\mathbf{N}$ & $\mathbf{r}_{\mathbf{p b}}$ & $\mathbf{p}$-value \\
\hline Two-Sided Market $(*)$ & 14 & 0.2657 & 0.0241 \\
Layer Player $(*)$ & 12 & 0.2464 & 0.0370 \\
Freemium $(+)$ & 28 & 0.2234 & 0.0592 \\
Integrator & 13 & 0.1566 & 0.1890 \\
Direct Selling & 24 & -0.1309 & 0.2731 \\
Open Business Model & 29 & 0.1251 & 0.2952 \\
Pay Per Use & 15 & 0.1203 & 0.3141 \\
Aikido & 12 & -0.1054 & 0.3782 \\
Digitization & 53 & 0.1034 & 0.3875 \\
\hline$+\mathrm{p}<0.10 ;{ }^{*}<0.05 ; * * \mathrm{p}<0.01$ & & & \\
\hline
\end{tabular}

Exemplary, Figure 3 visualizes how the correlation effects of the Freemium pattern $\left(r_{p b}\right.$ $=0.2234$ ) are manifested in our data. The interquartile range for the received seed funding of startups that applied the Freemium pattern $(\mathrm{n}=28)$ begins at $\$ 1 \mathrm{M}$ and ends at $\$ 4.23 \mathrm{M}$ with a median of $\$ 2.46 \mathrm{M}$. For startups that did not apply the pattern $(\mathrm{n}=$ 44 ), the $25^{\text {th }}$ percentile is $\$ 0.67 \mathrm{M}$, and the $75^{\text {th }}$ percentile is $\$ 2.84 \mathrm{M}$, with a median of $\$ 1.58 \mathrm{M}$.

Figure 3. Boxplot for Freemium Pattern

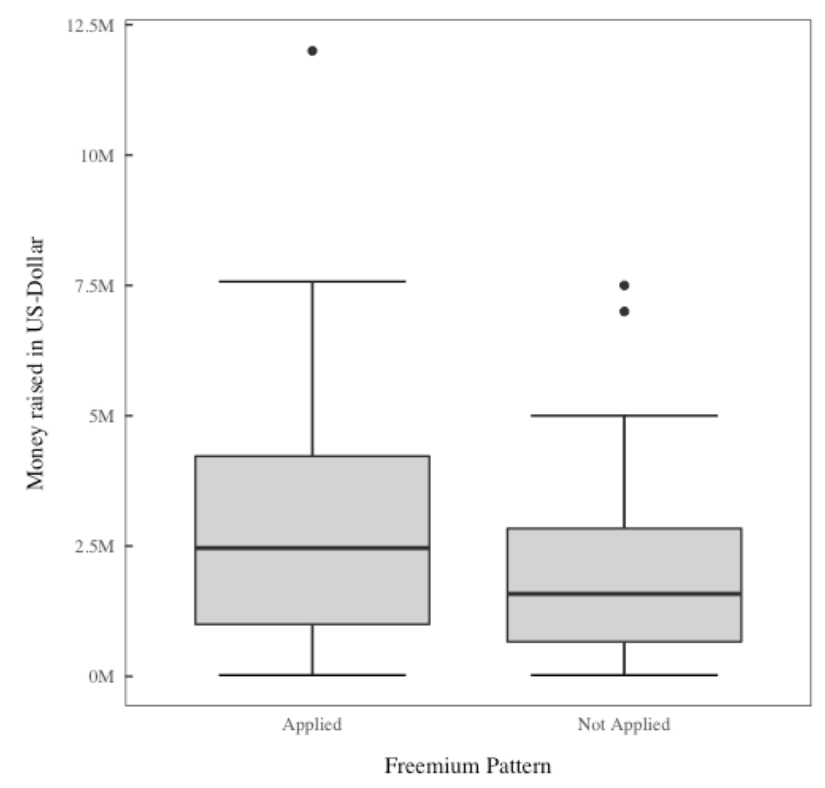

Table 4 shows the results of our correlation analysis for high-level patterns. The data indicate that specifying a Value Network pattern correlates with higher seed funding at $r=0.3149$, yet with a low p-value of 0.007. Applying Pricing Model, Revenue Stream, Multi-Sided Platform, or Value Proposition pattern also correlates with a slight increase 
in seed funding. Conversely, using the Merchant Model pattern correlates with a slight decrease.

Table 4. Pearson's Product-Moment Correlations for High-Level Patterns

\begin{tabular}{llll}
\hline Business Model Pattern & $\mathbf{n}$ & $\mathbf{r}_{\mathbf{p b}}$ & $\mathbf{p}$-value \\
\hline Value Network $(* *)$ & 33 & 0.3149 & 0.0071 \\
Pricing Model & 35 & 0.1769 & 0.1370 \\
Revenue Stream & 59 & 0.1269 & 0.2880 \\
Multi-Sided Platform & 33 & 0.1264 & 0.2900 \\
Merchant Model & 25 & -0.1198 & 0.3161 \\
Value Proposition & 53 & 0.1117 & 0.3504 \\
\hline$+\mathrm{p}<0.10 ; * \mathrm{p}<0.05 ; * * \mathrm{p}<0.01$ & & & \\
\hline
\end{tabular}

\section{Discussion}

Business model research argues that the business model has its share of influence on firm performance. By applying the concept of business model patterns on a sample of 72 US-startups, we analyzed the correlation between seed funding and business models. First, we showed the effects of 55 patterns elaborated by Gassmann, Frankenberger and Csik [24]. Second, we grouped our original patterns to analyze eight high-level patterns based on research from Weking, Hein, Böhm and Krcmar [38]. We identified three business model patterns (Two-Sided Market, Layer Player \& Freemium) and one higher-level pattern (Value Network) that lead to significantly higher seed funding.

Multiple other studies have investigated the impact of the business model in various economic contexts and for different types of firms [22, 41-44]. However, in organizational research, many factors interrelate and emerge towards firm performance $[45,46]$. Researchers' difficulty is to account for these interrelations of complex business ecosystems [47, 48]. Unlike other fields, e. g. medical research, experiments where these factors can be isolated are seldomly persuadable. With this study, we chose the context of early-stage startups. We argued that in this stage the business model is of higher importance since it highlights the startups' plans about their unique value proposition, value creation and capture mechanisms as well as their in this stage activities to implement them [3]. Even though this does not isolate the business model from other influences such as personality traits of founders or previous entrepreneurial experience, it increases its impact on the outcome.

We found the strongest correlational effect for the business model pattern of twosided markets. This pattern is also known as the platform business model that became increasingly popular through digital innovation, created the so-called "platform economy" and disrupted many industries such as mobility, retail, and sports. This popularity, caused by several highly successful startups such as Uber, Amazon, and Urban Sports Club, leads to investors' high expectations. As we noted earlier, early stage investors need to rely on the idea of the startup. Applying a business model that has been successful in other industry contexts provides an opportunity for a successful startup. However, research on digital platforms finds that such markets are often 
characterized by winner-takes-all markets and first-mover advantages [49]. A startup trying to establish its digital platform either in a new market or as a competition to another platform needs to scale fast. The network effects that can and need to be achieved in these markets require the early investment and early success of the platform. If this success is not achieved, it is more likely for the startup to fail. In their study on startups' chances for survival Weking, Böttcher, Hermes and Hein [17] found this negative correlation between the two-sided market pattern and startup survival. Also noting the relatively low number of startups applying this pattern in our analysis, we see the high-risk early-stage investors take when investing in a two-sided market startup. Hence, if they do so, they invest more to increase the chances that the startup can leverage network effects and gain early market success.

Similarly, the Layer Player pattern profits from economies of scale. The pattern describes companies that add single activities to the value creation in a value chain. Therefore, they engage in multiple ecosystems. Just like a digital platform, that needs to leverage network effects and grow fast, a Layer Player needs to establish its service in multiple industries quickly and scale its operations. As seed investors often supply more than just money, e. g. their network, the startups profit from the investment to use the money and the network to establish their services. Connecting the startup in their network shows the trust an investor has in the idea. This trust then manifests in the amount of investment. In their study Weking, Böttcher, Hermes and Hein [17], found that this pattern correlates with startup failure. They argue that it is difficult to establish the service in different industries, as they are often dominated by established players. As their study did not account for the role of investors for startup survival, our findings may propose future research on the influence of seed investment on survival after a specific time.

For the Freemium pattern, we found that the median investment is nearly one million US\$ higher for startups applying this pattern. Like the previously discussed patterns, the Freemium pattern also has gained popularity through the digital transformation. We observe this pattern in almost all areas of digital services such as media (e. g. Spotify), cloud storage (e. g. Dropbox), cloud computing (e. g. AWS) or productivity (e. g. Endnote). The idea behind this pattern is to provide free basic and paid premium services, where the premium customers cross-finance the free offering. Unlike the previous two patterns, this pattern is not centrally related to the value proposition but the value capture. Based on previous research, users are more likely to buy a service or product after being able to test it for free. The challenge for startups applying this pattern is to convert as many users to the premium service as possible. The seed funding helps to create an appealing premium service early, e. g. by providing the most popular music, and to establish the customer base. If the startup succeeds with this, research indicates a higher chance of survival, thus a return on investment for the investors [17].

One may assume that high funding results in higher chances for startup success. However, for the patterns two-sided market and layer player, our results and the results of Weking, Böttcher, Hermes and Hein [17] do not support this assumption. While our results show higher seed funding for these patterns, their research indicates lower chances of survival of startups. As argued above, the two patterns engage in highly competitive ecosystems. The funding is needed to establish the startup and capture its 
share of the value. The popularity and success of connected and integrated business models like digital platforms, e. g. Uber, Amazon, and Urban Sports Club lead to high expectations, thus high investments. However, the lower chances of survival indicate that high early-stage funding does not correlate with startup survival in these ecosystems. Investments in such business models take a high risk in the hope that they will also yield a high reward.

On a higher level, patterns related to the value network are of particular interest for investors. These patterns describe business models that add value-creating activities to a network, participate in the value capture, and generally have close interaction with other business models in their network [38]. For example, we observe such close interactions in digital platform ecosystems, where platform owners, sponsors, complementors, and customers have close interaction. The platform owner is especially interested in keeping his network connected to create lock-in effects to avoid users switching to other platforms. For investors, startups participating in such an interacting network seem worth an investment as they often integrate into existing profitable networks.

\subsection{Contributions to Research}

Our paper makes three theoretical contributions. First, we contribute to business model research. As an articulation of a firm's strategy and the planned activities to implement this strategy, the business model provides a novel lens to analyze different strategies' performance. Our results show that the business model influences the amount of seed funding received by a startup. The findings contribute to acknowledging that the business model is a source of competitive advantage and superior firm performance [50-53]. We address several calls for research $[16,54,55]$. We provide quantitative, industry-independent results to demonstrate business model performance, thus achieve generalizability. The identification of specific, tangible business model patterns supports the understanding that the business model is a source of competitive advantage.

Second, we contribute to entrepreneurship research by providing further explanations of startup performance. Our results show how startups with different business models receive different amounts of seed investment. In particular, we identify three business model patterns (two-sided market, layer player, and freemium) that significantly increase the investment sum. As funding is an essential factor for startup success [2], this contributes to the discussion about the influence of the business model on startup success [56].

Third, we contribute to research on ecosystems. Driven by the rapid development of digital technologies, today's business environment is characterized by complexity and uncertainty [47]. Firms become more and more intertwined, and value is created by firm networks rather than value chains [57]. For these networks, the theory of the ecosystem has emerged recently [58]. We show that investors invest more money in platform business models (two-sided market) that try to create a new platform ecosystem and in layer players that add services to complex firm networks. This 
supports the business model as a unit of analysis to analyze how firms create and capture value in ecosystems $[59,60]$.

\subsection{Contributions to Practice}

For practice, we provide insights from both the startup and the investor perspective. Our research provides indications for entrepreneurs when designing their business models. The knowledge that some business models receive higher startup funding than others highlights the importance of business model design. We argue that the identified patterns two-sided market, layer player, and freemium also require a higher investment, in the beginning, to get the business started and establish the startup's value proposition in the respective market. For investors, we observe a preference for business models integrated into their ecosystem. The results provide guidance for investment decisions. Depending on their risk aversion, different patterns, that we showed to receive more funding, provide higher chances of receiving a return on investment. As we discuss that the identified patterns require more capital to become successful and full commitment of the investor is needed in the early stages of the startup, early-stage investors can decide whether they can provide this investment and commitment.

\subsection{Limitations}

While this paper provides first insights on the effects of business model patterns on early-stage financing, it is subject to some limitations. First, the identified patterns are not the perfect way to receive seed investment. As earlier research highlights, there is no one successful business model [51,61]. Designing a business model is as much art as systematic [12], so creativity and innovativeness play an essential part for startups to succeed. Second, the business model is a dynamic construct, thus changes over time [62]. Our research only provides a static snapshot of the business model at the time of our coding. Thus, the result may only be valid for a specific time frame, and the successful patterns in different macro-economic context may change. Third, our sample size of 72 startups limits generalizability. Even though we were able to identify significant correlations, the analysis should be repeated on a larger sample. We also focused on US startups only to account for differences in the available capital for seed investment. Thus, our results may be limited to US firms and may be compared with analysis for different markets.

\section{Conclusion and Future Research}

The importance of startups for an economy is often highlighted in entrepreneurship research. Startups produce innovations, create jobs, and drive economic growth. However, only a few startups survive. Seed investment is crucial for many startups, as capital is a valuable but missing resource. Also, startups can profit from the knowledge and network of their investors. This research provides an analysis of the influence of the business model on the received early-stage investments. Based on a sample of 72 
US-startups, we identify three business model patterns that lead to higher seed investments: two-sided market, layer player, and freemium.

Further research should elaborate on the relationship between business models, startup funding, and startup survival [7]. The business model, need for external financing, and related firm performance change during the different stages of business development [56]. To cope with the challenge of startup success, time-series data, and control variables that account for ecosystem complexity may provide insights into this relationship and its development in different stages of the startup. Through longitudinal time-series, the evolution, adaptions, and various influences of the business model may become observable and provide a better understanding of the success and failure of startups and clarify the paradoxes in research.

\section{$7 \quad$ Acknowledgement}

The authors would like to thank the track chairs, editors and all anonymous reviewers for their helpful comments and suggestions. We thank the German Federal Ministry for Economic Affairs and Energy for funding this research as part of the project 01MK20001B (Knowledge4Retail).

\section{References}

1. $\quad$ Burnett, M.: Shark Tank. Sony Pictures Television, USA (2009)

2. Amara, N., Halilem, N., Traoré, N.: Adding value to companies' value chain: Role of business schools scholars. Journal of Business Research 69, 16611668 (2016)

3. Doganova, L., Eyquem, M.: What Do Business Models Do? Innovation Devices in Technology Entrepreneurship. Research Policy 38, 1559-1570 (2009)

4. Fisher, G., Kotha, S., Lahiri, A.: Changing with the Times: An Integrated View of Identity, Legitimacy, and New Venture Life Cycles. Academy of Management Review 41, 383-409 (2016)

5. Islam, M., Fremeth, A., Marcus, A.: Signaling by early stage startups: US government research grants and venture capital funding. Journal of Business Venturing 33, 35-51 (2018)

6. Bachher, J.S.G., Paul D.: Financing Early Stage Technology Based Companies: Investment Criteria Used By Investors. (1996)

7. Antretter, T., Blohm, I., Grichnik, D.: Predicting Startup Survival from Digital Traces: Towards a Procedure for Early Stage Investors. In: International Conference on Information Systems (ICIS). (Year)

8. Amar, K.A., Agrawal; Alok, Choudhary: Predicting the Outcome of Startups: Less Failure, More Success. (2016) 
9. Scott, E.L., Shu, P., Lubynsky, R.M.: Are 'Better' Ideas More Likely to Succeed? An Empirical Analysis of Startup Evaluation. Harvard Business School Working Papers (2015)

10. Saini, A.: Picking Winners: A Big Data Approach To Evaluating Startups And Making Venture Capital Investments. Massachusetts Institute of Technology (2018)

11. Susan C., L.R.A., Davidson;: Applications of the business model in studies of enterprise success, innovation and classification: An analysis of empirical research from 1996 to 2010. (2012)

12. Teece, D.J.: Business Models, Business Strategy and Innovation. Long Range Planning 43, 172-194 (2010)

13. Zott, C., Amit, R.: Business Model Design: An Activity System Perspective. Long Range Planning 43, 216-226 (2010)

14. Massa, L., Tucci, C.L., Afuah, A.: A Critical Assessment of Business Model Research. Acad. Manag. Ann. 11, 73-104 (2017)

15. Böhm, M., Weking, J., Fortunat, F., Mueller, S., Welpe, I., Krcmar, H.: The Business Model DNA: Towards an Approach for Predicting Business Model Success. In: 13. Internationale Tagung Wirtschaftsinformatik (WI 2017), pp. 1006 - 1020. (Year)

16. Zott, C., Amit, R., Massa, L.: The Business Model: Recent Developments and Future Research. Journal of Management 37, 1019-1042 (2011)

17. Weking, J., Böttcher, T., Hermes, S., Hein, A.: Does Business Model Matter for Startup Success? A Quantitative Analysis. In: 27th European Conference on Information Systems. (Year)

18. Haddad, H., Weking, J., Hermes, S., Böhm, M., Krcmar, H.: Business Model Choice Matters: How Business Models Impact Different Performance Measures of Startups. pp. 828-843 (2020)

19. Magretta, J.: Why business models matter. Harv. Bus. Rev. 80, 86-+ (2002)

20. v. Alberti-Alhtaybat, L., Al-Htaybat, K., Hutaibat, K.: A knowledge management and sharing business model for dealing with disruption: The case of Aramex. Journal of Business Research 94, 400-407 (2019)

21. Osiyevskyy, O., Dewald, J.: Inducements, Impediments, and Immediacy: Exploring the Cognitive Drivers of Small Business Managers' Intentions to Adopt Business Model Change. Journal of Small Business Management 53, 1011-1032 (2015)

22. Zott, C., Amit, R.: Business Model Design and the Performance of Entrepreneurial Firms. Organization Science 18, 181-199 (2007)

23. Zott, C., Amit, R.: The fit between product market strategy and business model: implications for firm performance. Strategic Management Journal 29, 1-26 (2008)

24. Gassmann, O., Frankenberger, K., Csik, M.: The Business Model Navigator: 55 Models That Will Revolutionise Your Business. Pearson, Harlow (2014)

25. Lanzolla, G., Markides, C.: A Business Model View of Strategy. Journal of Management Studies in press, 14 (2020) 
26. Hedman, J., Kalling, T.: The business model concept: theoretical underpinnings and empirical illustrations. European Journal of Information Systems 12, 49-59 (2003)

27. Teece, D.J.: Business models and dynamic capabilities. Long Range Planning 51, 40-49 (2018)

28. Chesbrough, H.: Business Model Innovation: Opportunities and Barriers. Long Range Planning 43, 354-363 (2010)

29. Shafer, S.M., Smith, H.J., Linder, J.C.: The power of business models. Business Horizons 48, 199-207 (2005)

30. Brettel, M., Strese, S., Flatten, T.C.: Improving the performance of business models with relationship marketing efforts - An entrepreneurial perspective. European Management Journal 30, 85-98 (2012)

31. Kulins, C., Leonardy, H., Weber, C.: A configurational approach in business model design. Journal of Business Research 69, 1437-1441 (2016)

32. Andries, P., Debackere, K.: Adaptation and Performance in New Businesses: Understanding the Moderating Effects of Independence and Industry. Small Business Economics 29, 81-99 (2006)

33. Fu, Y., Tietz, M.A.: When do investors prefer copycats? Conditions influencing the evaluation of innovative and imitative ventures. Strategic Entrepreneurship Journal 13, 529-551 (2019)

34. Cavallo, A., Ghezzi, A., Dell'era, C. and Pellizzoni, E.: Fostering Digital Entrepreneurship from startup to scaleup: The role of Venture Capital funds and Angel Groups. (2019)

35. Marra, A., Antonelli, P., Dell'Anna, L., Pozzi, C.: A network analysis using metadata to investigate innovation in clean-tech - Implications for energy policy. Energy Policy 86, 17 (2015)

36. Sheskin, D.: Handbook of Parametric and Nonparametric Statistical Procedures. CRC Press, Boca Raton (2004)

37. Remane, G., Hanelt, A., Tesch, J., Kolbe, L.: The Business Model Pattern Database - A Tool For Systematic Business Model Innovation. International Journal of Innovation Management 21, (2017)

38. Weking, J., Hein, A., Böhm, M., Krcmar, H.: A hierarchical taxonomy of business model patterns. Electronic Markets (2018)

39. Osterwalder, A., Pigneur, Y.: Business model generation: a handbook for visionaries, game changers, and challengers. Osterwalder \& Pigneur, Amsterdam (2010)

40. Althouse, A.D., Soman, P.: Understanding the true significance of a P value. Journal of Nuclear Cardiology 24, 191-194 (2017)

41. Pati, R.K., Nandakumar, M.K., Ghobadian, A., Ireland, R.D., O'Regan, N.: Business model design-performance relationship under external and internal contingencies: Evidence from SMEs in an emerging economy. Long Range Planning 51, 750-769 (2018)

42. Kim, S.K., Min, S.: Business Model Innovation Performance: When does Adding a New Business Model Benefit an Incumbent? Strategic Entrepreneurship Journal 9, 34-57 (2015) 
43. Morris, M.H., Shirokova, G., Shatalov, A.: The Business Model and Firm Performance: The Case of Russian Food Service Ventures. Journal of Small Business Management 51, 46-65 (2013)

44. Tavassoli, S.A.M., Bengtsson, L.: The Role of Business Model Innovation for Product Innovation Performance. Int. J. Innov. Manage. 22, (2018)

45. Park, Y., Mithas, S.: Organized Complexity of Digital Business Strategy: A Configurational Perspective. MIS Quarterly 44, 85-127 (2020)

46. Zhang, M., Chen, H., Lyytinen, K.: PRINCIPLES OF ORGANIZATIONAL CO-EVOLUTION OF BUSINESS AND IT: A COMPLEXITY PERSPECTIVE. 27th European Conference on Information Systems (ECIS), Stockholm \& Uppsala, Sweden (2019)

47. Benbya, H., Nan, N., Tanriverdi, H., Yoo, Y.: Complexity and Information Systems Research in the Emerging Digital World. MIS Quarterly (2020)

48. Tanriverdi, H., Rai, A., Venkatraman, N.: Research Commentary-Reframing the Dominant Quests of Information Systems Strategy Research for Complex Adaptive Business Systems. Information Systems Research 21, 822-834 (2010)

49. Schilling, M.A.: Technology Success and Failure in Winner-Take-All Markets: The Impact of Learning Orientation, Timing, and Network Externalities. The Academy of Management Journal 45, 387-398 (2002)

50. Amit, R., Zott, C.: Value Creation in E-Business. Strategic Management Journal 22, 493-520 (2001)

51. Brea-Solís, H., Casadesus-Masanell, R., Grifell-Tatjé, E.: Business Model Evaluation: Quantifying Walmart's Sources of Advantage. Strategic Entrepreneurship Journal 9, 12-33 (2015)

52. Casadesus-Masanell, R., Zhu, F.: Business model innovation and competitive imitation: The case of sponsor-based business models. Strategic Management Journal 34, 464-482 (2013)

53. Böttcher, T., Weking, J.: Identifying Antecedents \& Outcomes of Digital Business Model Innovation. 28th European Conference on Information Systems, Marrakesh (2020)

54. Lambert, S., Davidson, R.: Applications of the business model in studies of enterprise success, innovation and classification: An analysis of empirical research from 1996 to 2010. European Management Journal 31, 668-681 (2013)

55. Al-Debei, M.M., Avison, D.: Developing a unified framework of the business model concept. European Journal of Information Systems 19, 359-376 (2010)

56. George, G., Bock, A.J.: The Business Model in Practice and its Implications for Entrepreneurship Research. Entrepreneurship Theory and Practice 35, 83$111(2011)$

57. Coltman, T., Tallon, P., Sharma, R., Queiroz, M.: Strategic IT alignment: twenty-five years on. Journal of Information Technology 30, 91-100 (2015)

58. Jacobides, M.G., Cennamo, C., Gawer, A.: Towards a Theory of Ecosystems. Strategic Management Journal 39, 2255-2276 (2018) 
59. Vial, G.: Understanding digital transformation: A review and a research agenda. The Journal of Strategic Information Systems 28, 118-144 (2019)

60. Fitzgerald, M., Kruschwitz, N., Bonnet, D., Welch, M.: Embracing Digital Technology: A New Strategic Imperative. Sloan Management Review 55, 113 (2013)

61. Weill, P., Malone, T., Apel, T.: The Business Models Investors Prefer. MIT Sloan Management Review 52, 17-19 (2011)

62. Demil, B., Lecocq, X.: Business Model Evolution: In Search of Dynamic Consistency. Long Range Planning 43, 227-246 (2010) 